\title{
Can Affirming National Identity Increase International Trust? Experimental Evidence from South Korean, Chinese, and Japanese Nationals
}

\author{
EUN BIN CHUNG*
}

\begin{abstract}
How can states with a history of conflict promote trust with one another? Distrust between South Korea-Japan and ChinaJapan aggravates security fears and limits institutional cooperation in the region. Existing studies support the promotion of a common, overarching identity (e.g. "Asian-ness") over a strong sense of national belonging. Are salient national identities harmful or helpful for increasing trust between countries? Applying the psychological theory of group-affirmation to an international context and integrating experimental methods from behavioral economics, I aim to examine whether affirming national identities can increase trust of another country. In a novel experiment with South Korean, Chinese, and Japanese participants, I find that group-affirmed individuals reported higher levels of trust, measured by payments in a trust game.
\end{abstract}

Keywords: Trust, National Identity, Group-Affirmation, South Korea, Japan, China, Experiments, Trust Game, Political Psychology

* Doctoral Candidate, The Ohio State University, USA;

E-mail: chung.372@osu.edu;

DOI: 10.16934 /isr.16.1.201506.75 


\section{INTRODUCTION}

How can countries with a history of conflict overcome distrust? Past interacttions of war and colonization often create negative images between states, adding a layer of suspicion to the uncertainty in others' intentions in international relations (Herrmann and Fischerkeller 1995, 415). Relations between South Korea-Japan and China-Japan are prime examples. Experts on Northeast Asia highlight distrust as "the critical driver in the region, with historical animosity constituting the initial negative template that informs behavior" (Cha 2003, 37, 39). Fraught with chronic distrust originating from a troubled past, time and again the countries have experienced disruptions in institutional cooperation and aggravated security fears (Chung 2015b).

As a way to reconcile groups, numerous studies have advocated an overarching sense of commonness, homogenization, or universalism that submerges existing group identities and downplays group differences (Adler and Barnett 1998, 3; Allport 1954, 24, 281; Gaertner and Dovidio 1993, 1; Haas 1958; Rosamond 2000; Nussbaum 1994; Ohmae 1995; Waldron 2002, 3; Barry 2002, 152; Lind 2008, 86; He 2008). Observers of international tension in Northeast Asia in particular tend to emphasize the negative effects of strong nationalisms in the region, regarding high attachment to the nation and national belongingness to be the undesirable culprits of conflict (French 2014; Lehmann 2013).

In contrast, I suggest a counter-intuitive way of increasing trust between groups through a reaffirmation of existing group identities. I share the assumption from social psychological studies that attachment to one's group does not necessarily entail hostility toward other groups (Brewer 1999, 429; Herrmann et al. 2009, 751), and combine this insight with ideas from group-affirmation (Sherman, Kinias, Major, Kim, and Prenovost 2007, 1101-1103), a variant of self-affirmation theory (Steele 1988, 262). Focusing on trust in the public, this study assumes that psychological mechanisms in the public can affect foreign policy attitudes. I utilize data from a pilot study conducted for a larger project on group-affirmation. Notwithstanding limitations from the sample and data, as a preliminary test the findings highlight numerous possibilities for future extensions of the study, such as experiments in the field and/or with representative samples, and potential connections to policy implications as well.

Ultimately, I argue that group-affirmation enhances trust between people from countries that struggle from historical animosity. In an original experiment integrating methods from psychology and behavioral economics, I examine whether affirmation of national identity can increase trust between people from South Korea, Japan, and China. I find that group-affirmed individuals reported higher levels of trust toward their foreign opponents in trust games. These findings suggest important implications for relations between South Korea, Japan, and China 
and reducing tension on a regional level as well.

I start below by noting the problems of distrust between South Korea-Japan and China-Japan, namely limited institutional cooperation and heightened security fears. I then review existing research that suggests a promotion of commonness across groups. As an alternative to such claims, I introduce group-affirmation, as a way of making national identity salient through a reflection of national values. In the sections that follow, I lay out my experimental design and results from my empirical analysis. Finally, I conclude with possible policy implications of the idea that strong group identities per se are not detrimental to group relations. Groupaffirmation could also apply to groups in tension within a community, as states that suffer from internal ethnic, linguistic, or religious divisions find that reconciliation of the groups does not have to involve an erosion of sub-identities. I end with a brief discussion of academic projects that could build on this study in the future.

\section{THE PROBLEM OF DISTRUST}

While various efforts to ease distrust between countries have been made, few have proven to be successful in Northeast Asia (Chung and Woo 2015). In previous research scholars anticipated an improvement in relations though thick economic interdependence (Keohane and Nye 1977, 122-132) or increased societal contact (Allport 1954, 41-43). In economic terms however, Japan and China already trade heavily: Japan has emerged as China's largest trading partner and China as second largest to Japan (MITI, Bureau of Statistics; Japan Statistical Yearbook, Trade Statistics of China, Japanese Ministry of Justice Annual Report of Immigration, various years). Individual contact is already intense, as millions of Chinese, Koreans and Japanese visit one another's countries annually as students, tourists and on business trips (Berger 2008, 99). But these effects have not spilled over into an alleviation of the chronic distrust.

Distrust is the key impediment to cooperation and reconciliation in Northeast Asia (Christensen 1999, 49; He 2007, 3, 11, 20; Kristof 1998, 38). Two main problems arise from the inability to trust between South Korea, Japan, and China: limits to institutional cooperation, and heightened security fears.

Across theoretical perspectives, international relations scholars have long emphasized the importance of trust to cooperation and peace (Copeland 2000; Jervis 1976, 1978; Keohane 1984; Kydd 2005; Larson 1997; Mearsheimer 1994; Waltz 1979; Wendt 1999). Realists pay attention to states' inability to trust one another as a major impediment to cooperate regardless of their motivations, leading to conflict even among rational security-seeking states (Copeland 2000, 15; Jervis 1976; Mearsheimer 2001, 31-32; Waltz 1979, 91-92, 118; 1988, 40). Trust is also essential in constructivists' view, as redefinition of self and other, from 
adversary to partner to friend, develops through the mechanism of trust (Wendt 1992; 1999, 358). Trust can generate a transformative process of interaction, reinforcing a spiral of cooperation (Wendt 1999, 358). The flipside of this view then implies that distrust can sustain a constant sense of insecurity. Both realist and constructivist perspectives contend that distrust in international relations can aggravate security fears.

Neoliberal institutionalists maintain that through institutions this problem of mistrust can be resolved. Institutions facilitate cooperation among individuals who might not otherwise trust one another (Keohane 1984). By lengthening the shadow of the future, facilitating linkages, and monitoring and implementing agreements, institutions mitigate the trust problems inherent to anarchy (Rathbun 2009, 350-351).

However, unlike the neoliberal institutionalist predictions, the institutional measures in places in East Asia have not generated or increased trust. Brian Rathbun $(2011,243)$ notes that for effective functioning of institutions, trust between states must come first as a precondition. Consistent with this view, what we are repeatedly witnessing in East Asia is a disruption in institutional cooperation due to chronic distrust (Berger 2008).

For example, unable to trust Japanese intentions, South Korea and China have repeatedly recalled ambassadors from Tokyo and cancelled summits even when these countries were negotiating with Japan about vital issues, such as North Korea's acquisition of nuclear weapons. For every failed diplomatic or trade negotiation, there arise claims that reflect a lack of trust as a cause (Cha 2003).

Specifically, distrust affects the "rationality" of relations, with negative consequences for regional institution-building (Cho and Park 2011, 267) despite "all the good structural reasons to cooperate" (Berger 2003b, 407). There is an increasingly greater need for cooperation through institutions in the area, as regional and global challenges related to security, economic, environmental and several other issue areas that states alone cannot manage become more significant (Yamamoto 2008, 21). But any type of institution building first requires some trust (Rathbun 2011, 243), and suspicion lasting from the past has disrupted these efforts.

On top of the uncertainty in intentions that causes a security dilemma in international relations, negative history adds another layer of distrust, further complicating efforts to repair relations between old adversaries (Glaser 1997, 171; Herz 1950, 157). Increasingly today, with China on the rise, Shinzo Abe clearly displaying a more nationalistic stance, and unpredictable action from North Korea, distrust could light a fire on the regional tension. The most pressing issue is a "reaction and counteraction" cycle between a rising China and rearming Japan, caught in a security dilemma that could lead to an arms race. Coupled with the insecurity mistrust provides, this volatile situation could quickly lead to disaster.

Recent commentary in the Japan Times noted that "a nationalistic storm is building throughout the region, [...] and conflict ... between China and Japan [,] 
now looks possible" (Forbes 2013). With changing dynamics in the region today, distrust poses a greater threat. On a systematic level, the rapid growth of China and instability of the shifting balances of power could provide grounds likely for conflict (Organski 1958; Organski and Kugler 1980; Gilpin 1981). Regionally, this type of conflict could occur if Chinese vow to make a comeback from what they remember to be " 100 years of humiliation" under imperial Japanese influence, or if Japan aims to defeat Chinese attempts to achieve primacy in East Asia. If distrust fuels traditional scenarios of self-help and conflict the emboldening effects of Chinese economic prosperity could be manifested in implementing these ambitions and a regional arms race (Betts 1993, 60-61; Bernstein and Munro 1997; Bracken 1999; Buzan and Segal 1995; Calder 1996; Cha 2003; Friedberg 1993; Klare 1993; Layne 1996; Roy 1994; Shirk 1997).

On a state level, experts point to the decline of communism as a source of legitimacy for the Chinese government and predict a turn to other sources for domestic support-most possibly, a nationalistic story (Pei 2012). If this is the case, the most likely "Other" will be Japan. If Chinese leadership turns to take a "statistnationalist stand" which, in Etel Solingen's (2007, 40-42) words, feeds on nationalistic emotion against other states and prioritizes military buildup, then we could forecast an arms race in an East Asian security dilemma, just as Solingen describes in the Middle East.

Such intentions are observable in Japanese actions in its various territorial disputes. Tokyo is in contest over the Takeshima/Dokdo Islands with South Korea and the Northern Territories/Kuril Islands with Russia, but among the most dangerous has been its competition with Beijing over the Senkaku Islands (The Japan Times 2013). Disagreement over the islands has sparked naval clashes, aerial chases, activist flotillas, and domestic protests (Bandow 2013). Regarding the Senkakus, Abe declared that "there is no room for diplomatic negotiations over [the islands]," and that, the solution necessitated, "if I may say at the risk of being misunderstood-physical force" (Forbes 2013).

Notwithstanding Japanese claims that Japan just wants to reclaim the status of a "normal country" that has the right to defend itself with its military, fundamental distrust causes many Chinese and Koreans to fear that Japan may resume its path of militarism. Viewing Japan as militarist makes the countries afraid to trust it as a true partner (Lind 2012), and this wariness of Japanese intentions could initiate a spiral of mistrust and an arms race.

\section{ROAD TO RECONCILIATION}

\section{National Identity}

A lasting question in the literature as well as policy debates on intergroup 
conflict has been on whether parties in adversarial relations are able to come closer to cooperation and reconciliation without having to weaken their national identities. Noticing clashes of strong nationalisms around the world in areas like East Asia, numerous studies in political science and social psychology have suggested, as a way to peaceful relations, a promotion of universalism that covers over existing identities (Mansfield and Mutz 2009; Kinder and Kam 2009; Rousseau and Garcia-Retamero 2007; Sniderman et al. 2004). This could be on the basis of a super-ordinate identity based on cosmopolitan values (Nussbaum 1994; Mazzini et al. 2009; Held 2003); a sense of "we-ness" in a common in-group (Gaertner and Dovidio 1993); integration that submerges sub-categories through individual contact (Allport 1954); a neo-functionalist spillover (Haas 1958; Rosamond 2000); strategies of assimilation (Waldron 2002; Barry 2002); supranational regionalism (Bache et al. 2011); or the homogenizing effects of globalization (Ohmae 1995).

I offer group-affirmation as a way of lessening conflict and opening gateways for cooperation via the opposite route: by strengthening, not weakening, extant group identities. Making national identities salient can boost international trust. While this idea may at first seem unlikely, it is actually consistent with the intuition that people with a secure sense of their identity are more able to deal with others in a calm, collected, and objective way. More on this is elaborated in the theory section below.

In addition, making national identities salient through group-affirmation is an easier and more realistic route to intergroup peace. I make this claim for three reasons. First of all, from what we are witnessing in our world, achieving peace through an erosion of national identities is not feasible. We live in an age of nationalism. Even with intensifying forces of globalization, most notably in places like East Asia, we have not seen a decline in national identities or nationalist tension (Chung 2015a).

Second, the aforementioned paths that involve some weakening or elimination of sub-identities is difficult and requires much time. National identities are often deeply socialized and affect members' everyday lives. In most cases people cannot simply choose or abandon group identities when it has some association with family, heritage, or bloodline.

Third, integrating into a larger group by downplaying sub-categories of identification is costly not just in terms of time or difficulty, but risky in that it has a possibility of backfiring as well. People want some sense of belonging (Brewer 2003), and any attempt of forceful integration at a faster pace than people feel comfortable will pose a threat to ontological security, prompting opposition (Mitzen 2006, 341). It is thus harder to expect positive outcomes of integration when the process requires doing away with identities that were ingrained into people's minds from a young age. Therefore, the plausibility of trust via waning or dissembling of categories of national identity is questionable. 


\section{Correcting the Unjust Past}

The unsuccessful policy Seoul and Beijing have been pursuing for decades is to pressure Tokyo for explicit contrition for Japan's past aggression and atrocities (The New York Times 2007; Christensen 1999; Kydd 1997; Friedberg 1993/1994; Berger 2003a). Although denials of past violence are detrimental to international reconciliation, considering the cost of prestige a governmental apology entails for domestic and international audiences, the plausibility of expecting an apology from Tokyo in the foreseeable future is debatable.

I suggest group-affirmation as a more viable and efficient way to improve intergroup sentiment by focusing on moving the psychological underpinnings of behavioral change, rather than mobilizing political resources to pressure past inflictor groups into an apology.

\section{THEORY AND HYPOTHESIS}

\section{Psychological Bias as Obstacle to Cooperation}

A key assumption of this project is that failure to resolve chronic distrust is rooted in defensive acceptance of information that perpetuates existing negative perception of the other. For this reason, I focus on psychological biases in the populace that hamper cooperation between groups. I define psychological biases as consisting of cognitive, affective, and behavioral tendencies that are sticky and last to the extent that they inhibit rational learning (Kahneman and Tversky 1972).

According to the findings of Balcetis and Dunning (2006, 612), when humans are processing incoming information they tend to experience cognitive inertia (Huff et al. 1992, 55), as preexisting beliefs tend to have larger weight and thus influence the acceptance of the information. Information that contradicts or is different from prior beliefs is likely to be disregarded as unreliable or unimportant.

Because people do not always update to information in a perfectly rational manner due to cognitive inertia, it could be that distrust between countries with a history of conflict is perpetuated. Strong negative images of the other make it harder for people to alleviate suspicion, even when facing information that assures potential benefits from cooperation.

\section{Self-Affirmation Theory}

Self-affirmation in social psychology, the parent theory of group-affirmation, offers a way individuals become more resilient to criticism, rejection, or other personal threats (Steele 1988). The idea is that when people have had a chance to 
reflect upon their values, this allows them to replenish their self-worthiness. Due to this affirmation exercise, they are able to react via rational updating rather than engage in defensive behavior.

According to self-affirmation theory, by making salient important aspects of one's life unrelated to a certain issue at hand that threatens one's self-worth, people can realize that their self-worth does not hinge on that immediate situation (Sherman and Cohen 2006, 187). In other words, by restoring some self-worth through another source that makes people feel better about themselves, they are able to accept incoming information in a less defensive way, even if the information undermines their prior beliefs.

In existing research, self-affirmation has been associated with increased trust between people (Aronson et al. 2002, 113), positive affect toward others (Crocker et al. 2008), and an enhanced likeliness to reach mutually beneficial agreements in negotiation with a counterparty (Cohen et al. 2000, 1151; Cohen et al. 2007, 415). Self-affirmation has also led to majority groups in societies acknowledging more guilt and shame regarding their discrimination of minority groups (Adams et al. 2006, 616), and to attenuating irrational escalation of commitment, which would otherwise lead to a radicalization of politics (Sivanathan et al. 2007).

\section{Group Affirmation}

Psychological research on self-affirmation has recently advanced into the examination of effects of self-affirmation on a collective level, or group-affirmation (Sherman and Cohen 2006; Gunn and Wilson 2011; Sherman and Kim 2005). However, these studies look at how self-affirmation on an individual level can reduce biases and defensiveness that stem from group identities (Sherman and Kim 2005, 109-110). The mechanism considered here is that self-affirmed individuals are reminded that there are other sources of self-worth other than their social identity with the group, thus allowing for a more evenhanded judgment and releasing them from the need to make group-serving judgments. In other words, through self-affirmation individuals realize, consciously or non-consciously, that their social identities are only one part of a larger, flexible self-system. In this way self-affirmation allows people to evaluate their groups independently of the way they evaluate themselves (Sherman and Cohen 2006). The difference here is that these studies regard social-identity to be just another source of the self-concept. Thus the self-affirmation process works on an individual level again. My study, however, examines the possibility of affirmation of people's group identities, as there are aspects of identity that are shared collectively by group-members. The very idea of a "culture" shared by a collective indicates that there exists a commonality in what comprises the meaning of being a group-member. Because there 
are group-values shared by the majority of the group, these could be affirmed via policy, education, media, or leaders' rhetoric.

For example, just as the self could be composed of several different domains such as political ideology, religion, or profession, a Korean person's idea of what it means to be Korean could consist of a number of things. These could include family values, working hard, and loyalty. For a large number of Koreans, having a general sense of an anti-Japanese sentiment could be one, but just one, of many other components of being Korean. By highlighting an alternative domain, people become able to systematically process, leading to more coolheaded reactions towards another nationality than previously.

The theoretical reasoning is thus that being reminded of other sources of one's group-worth removes one from motivated reasoning that is dominated by images of distrust. This type of group-affirmation is expected to take people out of "the little hole of hatred they are in" that overwhelms judgment, and by being reminded of important transcendent values, people come to have a larger sense of the self (Crocker et al. 2008). This allows them to see the bigger picture in a more objective way. Group-affirmation therefore corrects group-serving judgments: by restoring group-worth, groups realize that social-identity does not hinge just on out-group hatred; they come to realize that cooperation is in their rational interest.

To summarize, I propose group-affirmation can increase levels of trust on an international level. Rather than finding alternative sources of self-worth that pertain to the individual but are unrelated to the social identity, people could restore integrity as a group by affirming values that are important to their group. This kind of group-affirmation could work through a mechanism similar to selfaffirmation in that people are reminded that the integrity and importance of their social identity do not rely only on opposition to the out-group or out-group hatred. By affirming some other value that is important to the group as a whole, people can react in a more evenhanded manner towards the out-group while being able to retain a sense of in-group attachment. This idea leads me to my hypothesis:

\section{$H=$ Group-affirmed individuals pay more tokens to their opponents than non-affirmed individuals in a trust game.}

\section{Scope Conditions}

I hypothesize that group-affirmation will increase trust between groups with a history of conflict. A word of caution is needed here, however: I do not propose group-affirmation as "the ultimate solution" for intergroup animosity, but rather as a catalyst for easing tension when certain conditions are met. By correcting for psychological biases and sticky images, group-affirmation could generate the first 
move towards affable relations, even if it is not the force that leads toward that as a final state. Initial trust generated by affirmation could become the first nudge necessary for initiating positive interaction that benefits both sides. It could be the case that once that minimum necessary level of trust is established, willingness to cooperate with each other opens, more easily giving rise to reciprocated games of cooperation.

In addition, in places where real security threats exist, such as between Israel and Palestine, group-affirmation could lose its strength. In such cases intractable conflict could be intuitively understood and chronic distrust seems more natural. There is no real puzzle there. Group-affirmation could be expected to be more effective in areas where there is persistent distrust between countries but where there is not much rational gain from hostility.

Another possible limit to group-affirmation is entrepreneurs with interests in exploiting and manipulating nationalism in a way that perpetuates out-group distrust. When nationalistic leaders with strong interests in promoting and maintaining domestic support based on chauvinism are in power, the group-affirmation effects can be overpowered. However, opposite cases also exist, where leaders believe in the benefits of establishing diplomatic relations and hope to cooperate with other states, but remain unable to make the move due to a potential public backlash. While group-affirmation could affect both leaders and the masses, in such cases group-affirmation could offer an attractive alternative where public opinion can be moved in a slightly moderate direction. In sum, the scope of this study is most applicable to cases where there is no realistic threat to survival, and no extreme determining force such as xenophobic elites who have overwhelming power over the country.

\section{EXPERIMENTAL ANALYSIS}

\section{Sample}

Experiments were conducted with undergraduate students at an American university who were nationals from South Korea, Japan, and China. The recruiting advertisement, which announced the study as "research on Northeast Asian political attitudes," specifically emphasized that only South Korean, Japanese, and Chinese nationals were invited to participate. This is because subjects with deeply-ingrained national identities provide the external validity that using a sample of American undergraduate students could not. Since the experiment involved affirmation of national identities and measured trust toward out-group members from a country in historical dispute with one's own country, I regarded it to be important to include subjects who were socialized into these ideas by the sufficient experience of living in their countries of origin. 
For this reason, within the survey the number of years subjects had lived in their Asian country of origin was also measured, in order to differentiate students who had lived most of their lives in the United States, for example $2^{\text {nd }}$ or $3^{\text {rd }}$ generation immigrants. I assume that these students could hold a different idea or strength of national identity.

\section{Research Design}

I examined the effect of group-affirmation on trust, where trust was measured by a trust game in which subjects thought they were playing against a foreign opponent. The two pairs of Japan-South Korea and Japan-China were examined, considering their historical relationship of past "inflictor" and "receiver" country. In other words, the levels of trust Japanese and South Korean subjects reported toward each other, and Japanese and Chinese subjects reported toward each other through trust games were measured. The dyad China-South Korea was not included in the study as it did not represent as strong of historical animosity and distrust as the other dyads did.

\section{(1) Procedures}

The experiment consisted of a series of sessions. Depending on which session subjects participated in, they were randomly placed into a treatment (group-affirmed) or control (non-affirmed) condition. That is, for each session all subjects were either affirmed or non-affirmed. Subjects walked into a computer lab to participate in what was advertised as a study on political attitudes. All responses were recorded in a computer. No conversation or other interaction between participants was allowed. Subjects were told that the experiment would consist of two unrelated studies, where the first task would involve a short writing task and the second part would involve a simple game of money exchange.

\section{(2) Experimental Manipulation: Group-Affirmation}

Subjects in the treatment condition received affirmation as a group, where they were given a list of 19 values that could be important to their Asian country of origin. Subjects were asked to rank these values in order of importance to people in their country, and then write a paragraph on why they thought the value they ranked as No.1 was most important to their country. Subjects in the control condition performed a non-affirmation task in place of the affirmation task, where they received a list of exotic-sounding jelly beans and were asked to rank them by how tasty they believed the flavors would be (Critcher et al. 2010, 950). 
Circle which one among the following values you think is most important to Koreans generally.

time management family democracy loyalty

creativity

originality

appearance/fashion

honesty

concern for others

patience

religion/spirituality

working hard

self-respect

friendships

personal liberty

health/fitness

achieving your dream social skills courtesy/manners

In the box provided below, write 1-2 paragraphs about why you think this value tends to be important to Koreans.

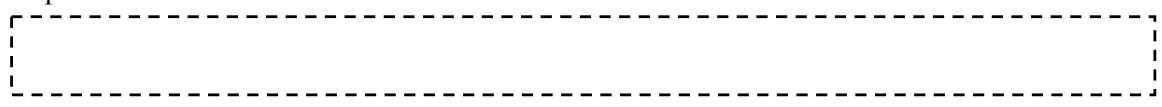

In the box provided below, write 1-2 paragraphs about what you think Koreans have done to demonstrate this value.

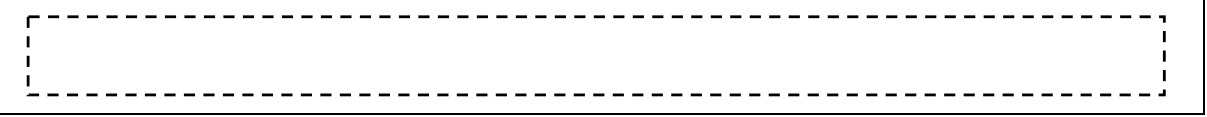

FIgURE 1. GROUP-AFFIRMATION MANIPULATION QUESTION

\section{(3) Measure of Trust: The Trust Game}

Trust was measured by a trust game, an economics-style experiment commonly used to gauge trust between players. The procedures of the game are as follows. In the game there is a proposer and a responder, where the proposer is given $\$ 10$ in virtual "tokens." The proposer must decide how much, if any, of the $\$ 10$ to send to the responder with the proviso that every $\$ 1$ sent is tripled before it reaches the responder. So, if the proposer sends $\$ 1$, the responder receives $\$ 3$, and if the proposer sends $\$ 5$, then the responder receives $\$ 15$, etcetera. Once the responder receives the money, then the responder must decide how much, if any, of the amount received to send back to the proposer.

The first move of the proposers represents trust. While proposers should realize that paying more money to the responder gives her/him a higher chance of getting a larger amount of money back, this is only so based on the condition that (s)he trust the responder to give some amount of that money back. In this particular study however, since each session consisted of either all affirmed or all nonaffirmed participants, it is worth examining the amount the proposer received back in the final step of each game. This is because affirmed proposers were paired with affirmed responders and non-affirmed players were likewise paired with each other. The final payment earned by proposers in this sense becomes a "collaborative product" by either affirmed or non-affirmed pairs.

The trust game is a good way to predict readiness to cooperate, because interaction in the game is analogous to situations states find themselves in when cooperating with one another. States must first invest some costs into the process; 
there is some time lag before the fruits of cooperation reach both actors. The trust between the two is what will allow for these states to put in these costs in the first place, with faith that there will be increasing returns.

In addition, when looking at the responder's side, her/his decision to give back a certain amount to the proposer is much like situations where cooperating states are dividing a pie. The pie is now bigger due to cooperation, as symbolized by the multiplication of the money by three. Division of the amplified pie at that point allows for mutual benefits, but this is possible only when both are willing to share the pie. Failure for the responder to give back any amount to the proposer, who was the one that allowed for any amplification of the pie in the first place, would imply that future and iterated cooperation would be difficult. At this point, even if there were attempts to initiate cooperative interaction, these would likely end in a one-time game, as the proposer would feel betrayed by the responder and anger at losing the money she gave away. Finding that the responder should not have been trusted, this could lead to even more conflict between the groups.

In my experiment, participants played a computerized trust game on z-Tree, the standard software used for economics experiments (Fischbacher 2007). All participants played 12 rounds of the game, although they were only informed they would be playing several rounds (and not exactly how many). Specifically, Chinese and Korean participants were told that they would be randomly paired with a new Japanese participant every time a new round of the game started. Some Japanese participants were told they would be playing with Chinese participants every time, while some Japanese participants were told they would play with Korean participants every time. In truth, regardless of subjects' nationality z-Tree randomly paired all subjects to play with anyone else in the room, who could be Japanese, Chinese, or South Korean. By this process of random assignment I assume that any differences in the "type" of opponent (including nationality and playing style, e.g. altruistic, trustworthy, self-interested, etc.) each subject was matched with are not systematic.

When participants played 12 rounds of the game, the experiment ended. All participants then filled out a simple questionnaire asking for simple demographics, political ideology, and for how many years they had lived in their Asian country of origin. Subjects randomly drew a number to determine which round, among the 12 rounds they played, their payment would be based on. All participants received the amount of money they made in that round of the game, were debriefed about the study, and left.

\section{Results}

An OLS regression of the collected data from my experiments shows that group-affirmation increased the amount of money participants earned, at a 0.1 
level of statistical significance. This indicates that group-affirmation did indeed lead pairs of Japanese-Chinese and Japanese-South Korean subjects to cooperate better with each other to produce overall larger gains from their interaction. Because of the way the game was structured, participants would have had to have some level of trust in the other to believe that there was a possibility of receiving some money back when they were offering some in the first place. Thus, I interpret this as a suggestion that group-affirmation increases levels of trust between players.

TABLE 1. GROUP-AFFIRMATION AND PAYMENT IN TRUST GAMES

\begin{tabular}{lcccc}
\hline & \multicolumn{2}{c}{ Average Payment } & $11^{\text {th }}$ Payment & $12^{\text {th }}$ Payment \\
& Coef./se & Coef./se & Coef./se & Coef./se \\
\hline Affirmation & 1.40 & 1.38 & 3.94 & 4.79 \\
& $(0.73)^{\dagger}$ & $(0.72)^{\dagger}$ & $(1.87)^{*}$ & $(2.05)^{*}$ \\
Gender & -0.20 & & -0.48 & 1.20 \\
& $(0.80)$ & & $(2.04)$ & $(2.24)$ \\
Years lived in Asian & -0.64 & -0.68 & -0.68 & -1.89 \\
country of origin & $(0.46)$ & $(0.44)$ & $(1.17)$ & $(1.28)$ \\
Political Ideology & 0.22 & & 0.17 & 0.04 \\
& $(0.56)$ & & $(1.43)$ & $(1.57)$ \\
\hline $\mathrm{N}^{\text {a) }}$ & & & & 54 \\
$\mathrm{R}^{2}$ & 0.09 & 0.09 & 0.08 & 0.12 \\
\hline
\end{tabular}

NOTE: Robust standard errors in parentheses. $\uparrow$ indicates statistical significance at the 0.90 level, ${ }^{*}$ at the 0.95 level, and ${ }^{* *}$ at the 0.99 level or greater.

a) A total of 54 subjects, consisting of 42 Chinese, 9 Koreans, and 3 Japanese, participated. In each ethnic group, approximately half ( 22 out of the 42 Chinese subjects, 4 out of the 9 Koreans, and 1 out of the 3 Japanese) were group-affirmed. On the whole, over 12 rounds of the game, the average amount all participants made was $\$ 9.59$.

Group-affirmed participants made $\$ 1.40$ more on average than non-affirmed participants. Other variables such as gender differences, the number of years participants lived in their Asian country of origin, and political ideology were not statistically significant.

After running a full model, I attempted a simplified model that excludes variables of gender and political ideology, and still found statistically significant effects between group-affirmation and average payment. This implies some plausibility to my theoretical claim.

Interestingly, among the different rounds of the game, group-affirmation had a statistically significant correlation with payments in the $1^{\text {st }}, 11^{\text {th }}$ and $12^{\text {th }}$ rounds. I have some tentative theoretical guesses as to why this could be. In the $1^{\text {st }}$ round, the effects of group-affirmation would have been most salient, as the time between when subjects completed the affirmation task and when they started playing the 
trust game was the shortest.

The statistical significance in the $11^{\text {th }}$ and $12^{\text {th }}$ rounds could have been because although participants were not aware these were the final stages of the game when they were playing, by that time, after a number of rounds participants came to learn that they could make more money if they "invested" more in the beginning of each round, where they needed to decide to give some money to their opponent. Even if this learning effect occurred for both group-affirmed and non-affirmed participants, I see from my results that group-affirmed participants could have found it easier to realize this and thus trusted their opponent with more ease as well. This finding is congruent with my theory that group-affirmation has the effect of taking people out of their narrow, defensive selves and anti-other mindset, and helps them learn the benefits of cooperating with the other in a rational and evenhanded way.

How generalizable and applicable are my results to real-world international politics? Some caveats to the possible policy connections of my experiment are equivalent to key points in general debates on the validity of experimental political science. One common critique assesses the reliability of convenience sampling. However, Druckman and $\operatorname{Kam}(2011,70)$ actually find that student subjects do not intrinsically pose a problem for a study's external validity, showing in meta-analyses that situations when student subjects are likely to constrain experimental inferences are relatively limited. Convenience samples pose a problem only when the size of a treatment effect depends upon a characteristic on which the convenience sample has virtually no variance (Druckman and Kam 2011, 70).

A related point of criticism hints at the artificiality of lab environments. Aronson et al. $(1990,82)$ explain that lab experiments are not necessarily limited in generalizability compared to field experiments. In fact, labs offer scholars tighter control over the treatment and experiment overall, making them a preferred option for those focusing on the internal validity and performance of their models. Aronson et al. $(1990,82)$ also note that "Bringing the research out of the laboratory does not necessarily make it more generalizable or "true"; it simply makes it different ... The generalizability of any research finding is limited. This limitation can be explicated only by systematically testing the robustness of research results across different empirical realizations of both the independent and dependent variables via systematic replication to test the extent to which different translations of abstract concepts into concrete realizations yield similar results."

\section{CONCLUSION}

Political elites and experts have yet to reach a consensus on best practices for existing identities when it comes to reconciliation between groups. In many cases of nationalistic or intrastate ethnic wars, the boundaries group identities draw bet- 
ween people are seen as the very cause of conflict itself, dividing people into an "us" vs. "the other." Also, theoretical predictions that globalization would accompany an erosion of nationalism have not been confirmed (Held and McGrew 2000; Guibernau2001; Kim 2000; Ohmae 1995; Hughes 2006). In the European Union (EU), one of the most tightly integrated regional entities in the world, historical trends demonstrate that regional identities form alongside extant national identities, adding to rather than replacing them (Hoffman 1966; Rosamond 2000).

Under these conditions, this pilot study presents possibilities for a more plausible approach of what to do with existing boundaries of identity. Although future extensions of this research could benefit from more representative samples across the countries, the findings in this study shed light on potential robustness of the mechanism of group-affirmation and its connection to increasing intergroup trust. Making a case for how stronger identification to sub-groups can actually improve relations between larger groups, in a broad sense my study offers timely implications for debates on multiculturalism, and interethnic and interracial conflict in domestic politics. If making salient existing sub-group identities via group-affirmation paves ways for a more peaceful coexistence within a supra-group, there is reason to be hopeful that multicultural communities where a number of different cultures coexist whilst defending each of their cultural traditions and practices can be free of conflict.

In the context of Northeast Asian states in particular, affirmation effects could potentially suggest a more feasible way of overcoming historical animosity than its alternatives, for example the policy of public apology. While it is morally just and satisfying to see past inflictors of harm atone for their guilt, state leaders are sensitive to issues of losing or saving face relative to other governments and how that is displayed to their domestic audiences (O’Neill 1999, Lind 2009). Unfortunately (yet also perhaps unsurprisingly), the pursuit of a public apology in Northeast Asia has been ineffective for decades.

If further research confirms the robustness of this study's findings, groupaffirmation could propose appealing policy advice for state leaders who wish to obtain the benefit of international cooperation with a past adversary but who are hesitant to do so due to public objections. With the current nationalistic vigor in South Korea, China, and Japan, it is unrealistic to expect a rapid diminishing of nationalisms in Northeast Asia. State leaders will thus need to engage nationalism for public support. This will be especially important in democratic states, where leaders must appear as fit and attractive enough to win votes into office. So when elites find economic, strategic, or geopolitical reasons to cooperate, group-affirmation could present a path to pursue this while still advocating popular nationalism.

In sum, when leaders hope to ease relations with other states but encounter challenges due to sticky enemy images in public opinion, group-affirmation may be able to help move the people out of motivated reasoning and towards a moderate 
direction. If this process works congruently with the proposed mechanism of group-affirmation, it would be through heightened ability of the masses to objectively and systematically process the benefits of international cooperation. As previously noted, there could also oppositely be times when countries have state leaders with strong interests in actively promoting distrust and hatred. In these cases there will be limits to the affirmation effects.

One way in which my study contributes to the crossroads of literature between international relations and social psychology is that I take an interdisciplinary approach to examine underlying psychological foundations of intergroup trust. Many international relations studies that explore international enmity focus on the final products of interaction; the external aspects of state behavior. An example is the influential research on enduring rivalries, which defines enduring rivalries as state dyads that have experienced at least five Militarized Interstate Disputes (MID) in the last 20 years (Goertz and Diehl 1992).

While these seminal findings have contributed to the growth of a rich body of literature, they do not look at the change that actually happens in people's minds when there is a turning point in state relations. The psychological approach of affirmation theory can attempt to fill this gap by focusing on the micro-mechanisms of perception that have a causal effect on international relations. Attention to the actual psychological underpinnings of enduring tension can contribute to more effectively identifying the causes of, and thus eventually relieving the "memory obstacle" that perpetuates a lack of trust.

There are several other related avenues to investigate in the future that will add to and strengthen this research. One is to see how long the effects of groupaffirmation last. Studies have proven effects of self-affirmation on students last for at least a year (Cohen et al. 2009, 400). How long group-affirmation might last has direct implications for how attractive and meaningful the application of affirmation for groups can be. Second, in future extensions of this study it would be helpful to clarify how affirmation-effects work through either similar or different mechanisms for the inflictor and receiver countries. Third, a separate examination of trust and trustworthiness would allow for a more refined analysis of exactly how affirmation increases trust. Related to this point, the effect of matching affirmed with nonaffirmed participants, and how learning may unfold differently in each case, would be an interesting case to investigate. Finally, as noted in my scope conditions, the potential risk of applying group-affirmation of national identities to real-world policy would be the danger of it springing in the undesired direction of xenophobia and self-glorification, especially in the case that chauvinistic entrepreneurs have an interest in promoting such outcomes. By carefully studying how the self-concept clarity enhanced by affirmation is related (or not) to self-esteem, one would be able to broaden the applicability of group-affirmation to policy. I would like to see if how enhanced in-group love exactly shows different effects from self-esteem 
based on a comparison of in-groups and out-groups, which would normally be a source of stronger out-group bias.

\section{REFERENCES}

Adams, Glenn, Teceta Thomas Tormala, and Laurie T. O'Brien. 2006. The Effect of Self-Affirmation on Perceptions of Racism. Journal of Experimental Social Psychology 42(5): 616-626.

Adler, Emanuel and Michael Barnett. 1998. Security Communities. Cambridge: Cambridge University Press.

Allport, Gordon. 1954. The Nature of Prejudice. Cambridge, MA: Perseus Books.

Aronson, Elliott, Phoebe C. Ellsworth, J. Merrill Carlsmith, and Marti Hope Gonzales. 1990. Methods of Research in Social Psychology, 2nd Ed. New York: McGraw-Hill.

Bache, Ian and George Andreou. eds. 2011. Cohesion Policy and Multi-level Governance in South East Europe, Oxford: Routledge.

Balcetis, Emily and David Dunning. 2006. See What You Want to See: Motivational Influences on Visual Perception. Journal of Personality and Social Psychology 91(4): 612-625.

Barry, Brian. 2002. Culture and Equality: An Egalitarian Critique of Multiculturalism. Harvard University Press.

Berger, Thomas. 2003a. The Construction of Antagonism: The History Problem in Japan's Foreign Relations. In Reinventing the Alliance: US-Japan Security Partnership in an Era of Change, eds. G. John Ikenberry and Takashi Inoguchi. New York: Palgrave.

Berger, Thomas. 2003b. Power and Purpose in Pacific East Asia: A Constructivist Interpretation. In International Relations Theory and the Asia-Pacific, eds. G. John Ikenberry and Michael Mastanduno, New York: Columbia University Press.

Berger, Thomas. 2008. Overcoming a Difficult Past: the History Problem and Institution Building in Northeast Asia. In Institutionalizing Northeast Asia: Regional Steps toward Global Governance, eds. Martina Timmermann and Jitsuo Tsuchiyama. Tokyo: United Nations University Press.

Bernstein, Richard and Ross Munro. 1997. The Coming Conflict with China. New York: Knopf.

Betts, Richard. 1993-1994. Wealth, Power, and Instability, International Security 18(3): 34-77.

Bracken, Paul. 1999. Fire in the East. New York: Harper Collins.

Brewer, Marilynn B. 2003. Optimal Distinctiveness, Social Identity, and the Self. In Handbook of Self and Identity, eds. Mark Leary and June Tangney. The Guilford Press. 
Brewer, Marilynn B. 1999. The Psychology of Prejudice: Ingroup Love or Outgroup Hate? Journal of Social Issues 55(3): 429-444.

Buzan, Barry and Gerald Segal. 1995. Asia: Skepticism about Optimism. National Interest 39.

Calder, Kent. 1996. Pacific Defense. New York: Morrow.

Cha, Victor D. 2003. Hypotheses on History and Hate in Asia: Japan and the Korean Peninsula. In Reconciliation in the Asia-Pacific, ed. Yoichi Funabashi. Washington, DC: United States Institute of Peace.

Cho, Il Hyun and Seo-Hyun Park. 2011. Anti-Chinese and Anti-Japanese Sentiments in East Asia: The Politics of Opinion, Distrust, and Prejudice. The Chinese Journal of International Politics 4(3): 265-290.

Chung, Eun Bin. 2015a. Explaining the Coexistence of Globalization and Nationalism in East Asia: An Analytical Framework on the Case of Hallyu (The Korean Wave), Peace Studies 23(1): 329-381.

Chung, Eun Bin. 2015b. Overcoming the History Problem: Group-Affirmation and Trust in International Relations. Ph. D. dissertation, The Ohio State University, forthcoming.

Chung, Eun Bin and Byungwon Woo. 2015. We Like You Better When We Feel Good About Ourselves: Group-Affirmation in an International Context. Korea Observer 46(2): 387-421.

Christensen, Thomas J. 1999. China, the U.S.-Japan Alliance, and the Security Dilemma in East Asia. International Security 23(4): 49-80.

Cohen, Geoffrey L., Joshua Aronson, J., and Claude M. Steele. 2000. When Beliefs Yield to Evidence: Reducing Biased Evaluation by Affirming the Self. Personality and Social Psychology Bulletin 26: 1151-1164.

Cohen, Geoffrey L., David K. Sherman, Anthony Bastardi, Lillian Hsu, Michelle McGoey, and Lee Ross. 2007. Bridging the Partisan Divide: Self-Affirmation Reduces Ideological Closed-Mindedness and Inflexibility in Negotiation. Journal of Personality and Social Psychology 93(3): 415-430.

Cohen, Geoffrey L., Julio Garcia, Valerie Purdie-Vaugns, Nancy Apfel, and Patricia Brzustoski. 2009. Recursive Processes in Self-Affirmation: Intervening to Close the Minority Achievement Gap. Science 324: 400-403.

Copeland, Dale. 2000. The Origins of Major War. Ithaca: Cornell University Press. Critcher, Clayton R., David Dunning, and David A. Armor. 2010. When Self-Affirmations Reduce Defensiveness: Timing is Key. Personality and Social Psychology Bulletin 36, 947-959.

Crocker, Jennifer, Yu Niiya, and Dominik Mischkowski. 2008. Why Does Writing about Important Values Reduce Defensiveness? Self-Affirmation and the Role of Positive, Other-Directed Feelings. Psychological Science 19: 740-747.

Druckman, James N. and Cindy D. Kam. 2011. Students as Experimental Participants: A Defense of the 'Narrow Data Base.' In Handbook of Experimental 
Political Science, eds. James N. Druckman, Donald P. Green, James H. Kuklinski, and Arthur Lupia. New York: Cambridge University Press, 41-57.

Fischbacher, Urs. 2007. z-Tree: Zurich Toolbox for Ready-made Economic Experiments. Experimental Economics 10(2): 171-178.

Friedberg, Aaron L. 1993-1994. Ripe for Rivalry: Prospects for Peace in a Multipolar Asia. International Security 18(3).

French, Thomas. 2014. The Cycle of Nationalism in North East Asia. International Relations and Security Network (ISN).

Gaertner, Samuel L., John F. Dovidio, Phyllis A. Anastasio, Betty A. Bachman, and Mary C. Rust. 1993. The Common Ingroup Identity Model: Recategorization and the reduction of intergroup Bias. European Review of Social Psychology 4: 1-26.

Gilpin, Robert. 1981. War and Change in World Politics. Cambridge, UK: Cambridge University Press.

Glaser, Charles L. 1997. The Security Dilemma Revisited, World Politics 50(1): 171-201.

Guibernau, Montserrat. 2001. Globalization and the Nation-State. In Understanding Nationalism. Montserrat Guibernau and John Hutchinson eds. London: Blackwell.

Gunn, Gregory R. and Anne E. Wilson. 2011. Acknowledging the Skeletons in Our Closet: The Effect of Group Affirmation on Collective Guilt, Collective Shame, and Reparatory Attitudes. Personality and Social Psychology Bulletin 37: 1474-1487.

Haas, Ernst B. 1958. The Uniting of Europe. Stanford: Stanford University Press.

He, Yinan. 2007. History, Chinese Nationalism and the Emerging Sino-Japanese Conflict. Journal of Contemporary China 16(50): 1-24.

He, Yinan. 2008. Ripe for Cooperation or Rivalry? Commerce, Realpolitik, and War Memory in Contemporary Sino-Japanese Relations. Asian Security 4(2): 162- 197.

Held, David and Anthony McGrew. 2003. The Great Globalization Debate: An Introduction' in Held, David and Anthony McGrew. Eds. The Global Transformations Reader. Cambridge: Polity Press.

Herrmann, Richard K. and Michael P. Fischerkeller. 1995. Beyond the Enemy Image and Spiral Model: Cognitive-Strategic Research after the Cold War. International Organization 49(3): 415-450.

Herrmann, Richard K., Pierangelo Isernia, and Paolo Segatti. 2009. Attachment to the Nation and International Relations: Dimensions of Identity and Their Relationship to War and Peace. Political Psychology 30(5): 721-754.

Herz, John. 1950. Idealist Internationalism and the Security Dilemma, World Politics 2(2): 157-180.

Hoffmann, Stanley. 1966. Obstinate or Obsolete? The Fate of the Nation-State and 
the Case of Western Europe. Daedalus 95(3): 862-915.

Huff James O., Anne S. Huff, and Howard Thomas. 1992. Strategic Renewal and the Interaction of Cumulative Stress and Inertia. Strategic Management Journal 13: 55-75.

Hughes, Christopher R. 2006. Chinese Nationalism in the Global Era. Oxon: Routledge.

Jervis, Robert. 1976. Perception and Misperception in International Politics, Princeton, NJ: Princeton University Press.

Jervis, Robert. 1978. Cooperation under the Security Dilemma, World Politics 30 (2): 167-214.

Kahneman, Daniel and Amos Tversky. 1972. Subjective Probability: A Judgment of Representativeness. Cognitive Psychology 3: 430-454.

Keohane, Robert. 1984. After Hegemony: Cooperation and Discord in the World Political Economy, Princeton, NJ: Princeton University Press.

Keohane, Robert and Joseph Nye. 1977. Power and Interdependence. Boston: Little, Brown.

Kim, Samuel. 2000 East Asia and Globalization: Challenges and Responses. in Kim, Samuel. Ed. East Asia and Globalization. New York: Rowman and Littlefield.

Kinder, Donald R. and Cindy D. Kam. 2009. Us Against Them: Ethnocentric Foundations of American Opinion. Chicago: University of Chicago Press.

Klare, Michael. 1993. The Next Great Arms Race. Foreign Affairs 72(3).

Kristof, N. D. 1998. The Problem of Memory. Foreign Affairs 77(6): 37-49.

Kydd, Anthony. 2005. Trust and Mistrust in International Relations, Princeton, NJ: Princeton University Press.

Larson, Deborah. 1997. Anatomy of Mistrust: US-Soviet Relations During the Cold War. Ithaca, NY: Cornell University Press.

Layne, Christopher. 1996. Less is More: Minimal Realism in East Asia. National Interest 43.

Lehmann, Jean-Pierre. 2013. Nationalism Rises in Northeast Asia. Yale Global. January.

Leland, J., D. Houser, and J. Shachat. 2005. Measuring Trust and Trustworthiness. In Trust and Entrepreneurship: A West-East Perspective. Hohmann, H.-H. and Welter, F. Edward Elgar Publishing: 87-96.

Lind, Jennifer. 2008. Sorry States: Apologies in International Politics. Ithaca: Cornell University Press.

Lind, Jennifer. 2012. Sorry I'm Not Sorry: The Perils of Apology in International Relations. Foreign Affairs. November 21.

Mansfield, Edward. D. and Diana C. Mutz. 2009. Support for Free Trade: SelfInterest, Sociotropic Politics, and Out-Group Anxiety. International Organization 63(3): 425-457. 
Mazzini, Giuseppe, N. Urbinati, and S. Recchia, eds. 2006. A Cosmopolitanism of Nations: Giuseppe Mazzini's Writings on Democracy, Nation Building, and International Relations. Princeton University Press.

Mearsheimer, John J. 1994. The False Promise of International Institutions. International Security 19(3): 5-49.

Mearsheimer, John J. 2001. The Tragedy of Great Power Politics. New York: Norton.

Mitzen, Jennifer. 2006. Ontological Security in World Politics: State Identity and Security Dilemma, European Journal of International Relations 12(3): 341370.

Nussbaum, Martha C. 1994. Patriotism and Cosmopolitanism. Boston Review 19 (5).

Organski, A. F. K. 1958. World Politics. New York: Alfred A. Knopf.

Organski, A. F. K. and Jacek Kugler. 1980. The War Ledger. University of Chicago Press.

Ohmae, Kenichi. 1995. The End of the Nation-State: the Rise of Regional Economies. New York: Simon and Schuster Inc.

Pei, Minxin. 2010. Rights and Resistance: The Changing Contexts of the Dissident Movement. In Chinese Society: Change, Conflict and Resistance, Elizabeth J. Perry and Mark Selden. Eds. New York: Routledge.

Rathbun, Brian C. 2009. It Takes All Types: Social Psychology, Trust and the International Relations Paradigm in Our Minds. International Theory 1(3): 345-380.

Rathbun, Brian C. 2011. Before Hegemony: Generalized Trust, International Cooperation and the Design of International Organizations. International Organization 45(2): 243-273.

Rosamond, Ben. 2000. Theories of European Integration. Palgrave Macmillan: Hampshire.

Rousseau, David L. and Rocio Garcia-Retamero. 2007. Identity, Power and Threat Perception: A Cross-National Experimental Study, Journal of Conflict Resolution, 51(5): 744-771.

Roy, Denny. 1994. Hegemon on the Horizon? International Security 19(1).

Sherman, David K. and Geoffrey L. Cohen. 2006. The Psychology of Self-defense: Self-affirmation Theory. Advances in Experimental Social Psychology 38: $183-242$.

Sherman, David K. and Heejung S. Kim. 2005. Is There an 'I' in 'Team'? The Role of the Self in Groupserving Judgments. Journal of Personality and Social Psychology 88(1): 108-120.

Sherman, David. K., Zoe Kinias, Brenda Major, Heejung S. Kim, and Mary Prenovost. 2007. The Group as a Resource: Reducing Biased Attributions for Group Success and Failure via Group-Affirmation. Personality and Social 
Psycho-logy Bulletin 33: 1100-1112.

Shirk, Susan. 1997. Asia-Pacific Regional Security: Balance of Power or Concert of Powers. in David Lake and Patrick Morgan. Eds. Regional Orders: Building Security in a New World. University Park, PA: Penn State University Press.

Sivanathan, Niro, Daniel C. Molden, Adam D. Galinsky, and Gillian Ku. 2008. The Promise and Peril of Self-affirmation in De-escalating Commitment. Organizational Behavior and Human Decision Processes 107(1): 1-14.

Solingen, Etel. 2007. Nuclear Logics: Contrasting Paths in East Asia and the Middle East. Princeton: Princeton University Press.

Sniderman, Paul M., Louk Hagendoorn, and Markus Prior. 2004. Predisposing Factors and Situational Triggers: Exclusionary Reactions to Immigrant Minorities. The American Political Science Review 98(1): 35-49.

Steele, Claude M. 1988. The Psychology of Self-Affirmation: Sustaining the Integrity of the Self. In Advances in Experimental Social Psychology. L. Berkowitz. Ed. New York: Academic Press 21.

Waldron, Jeremy. 2002. One Law for All-The Logic of Cultural Accommodation. Washington and Lee Law Review 59: 3.

Waltz, Kenneth. 1979. Theory of International Politics, 1st edn., Boston, MA: McGraw-Hill.

Wendt, Alex. 1999. Social Theory of International Politics, Cambridge, UK; New York: Cambridge University Press.

Wendt, Alex. 1992. Anarchy is What States Make of It: The Social Construction of Power Politics. International Organization 46: 391-425.

Yahuda, Michael. 2006. The Limits of Economic Interdependence: Sino-Japanese Relations. in Johnston, A. and Ross, R., eds., New Directions in the Study of China's Foreign Policy. Stanford University Press.

Yamamoto, Yoshinobu. 2008. Institutionalization in Northeast Asia: Is Outside-In Regionalization Enough? in Martina Timmermann and Jitsuo Tsuchiyama, eds., Institutionalizing Northeast Asia: Regional Steps Toward Global Governance. Tokyo: United Nations University Press. 